\title{
OVERVIEW OF 2012 FIELD STUDIES: UPPER ALASKA PENINSULA AND WEST SIDE OF LOWER COOK INLET, ALASKA \\ by
}

\author{
Robert J. Gillis ${ }^{1}$, Editor
}

Cook Inlet field studies carried out in summer 2012 by the Alaska Division of Geological \& Geophysical Surveys (DGGS) and Alaska Division of Oil and Gas (DOG) in collaboration with the U.S. Geological Survey (USGS) focused on Mesozoic forearc basin stratigraphy at selected locations on the western margin of the inlet and the upper Alaska Peninsula (fig. 1). This work builds on similar studies performed by DGGS, DOG, and the USGS in the summers of 2009 and 2010 that were designed to collect baseline geologic data about the greater Cook Inlet Mesozoic petroleum system and develop a better understating of the depositional and structural history of the Mesozoic forearc basin. To date, more than 20 stratigraphic sections have been measured from the Tuxedni Group, and the Chinitna, Naknek, and Kaguyak Formations, as well as unnamed Upper Cretaceous rocks near Saddle Mountain by DGGS (LePain and others, 2011) (fig. 2). Additionally, more than 500 samples have been collected or analyzed for porosity and permeability, sandstone petrography, hydrocarbon seal capacity, organic geochemistry, geochronology, and thermochronology, among others, most of which are tied to measured sections. Results of these studies and analyses will be made available to the public in a series of reports published through DGGS in the coming months. Plans are underway for additional field studies in this area in 2013 and beyond, including new geologic mapping of the Iniskin Peninsula area.

The chapters in this report briefly summarize highlights of our 2012 Cook Inlet field campaign, offering only preliminary impressions of field observations, and serving as precursors to a series of raw data files and detailed interpretive reports about the geologic evolution of Cook Inlet basin and components of its petroleum system. Progress reports such as these will continue to be published to provide timely updates of critical new findings and as supplements to future technical reports.

Topics discussed below first address exposures of petroleum source rocks to Cook Inlet basin, followed by conventional reservoir quality, fracture analyses of Jurassic and Cretaceous strata, occurrences of hydrocarbon saturation of Mesozoic sandstones, and conclude with the tectonic controls for the Mesozoic forearc basin based on preliminary structural and stratigraphic studies:

- Reconnaissance studies of potential petroleum source rocks in the Red Glacier Formation of the Tuxedni Group (Stanley and others)

- Field observations of reservoir quality for the Naknek and Kaguyak Formations (Helmold)

- Fracture studies in Naknek and Kaguyak Formation strata (Gillis and others)

- Observations from a hydrocarbon-bearing sandstone in the Naknek Formation (Stanley and others)

- Preliminary observations about the stratigraphy and occurrence of hydrocarbon in Kaguyak Formation rocks (Wartes and others)

- Observations and preliminary interpretations of the Bruin Bay fault system (Gillis and others)

- Tectonic controls on Naknek Formation deposition (Wartes and others)

'Alaska Division of Geological \& Geophysical Surveys, 3354 College Rd., Fairbanks, Alaska 99709-3707; bob.gillis@alaska.gov 


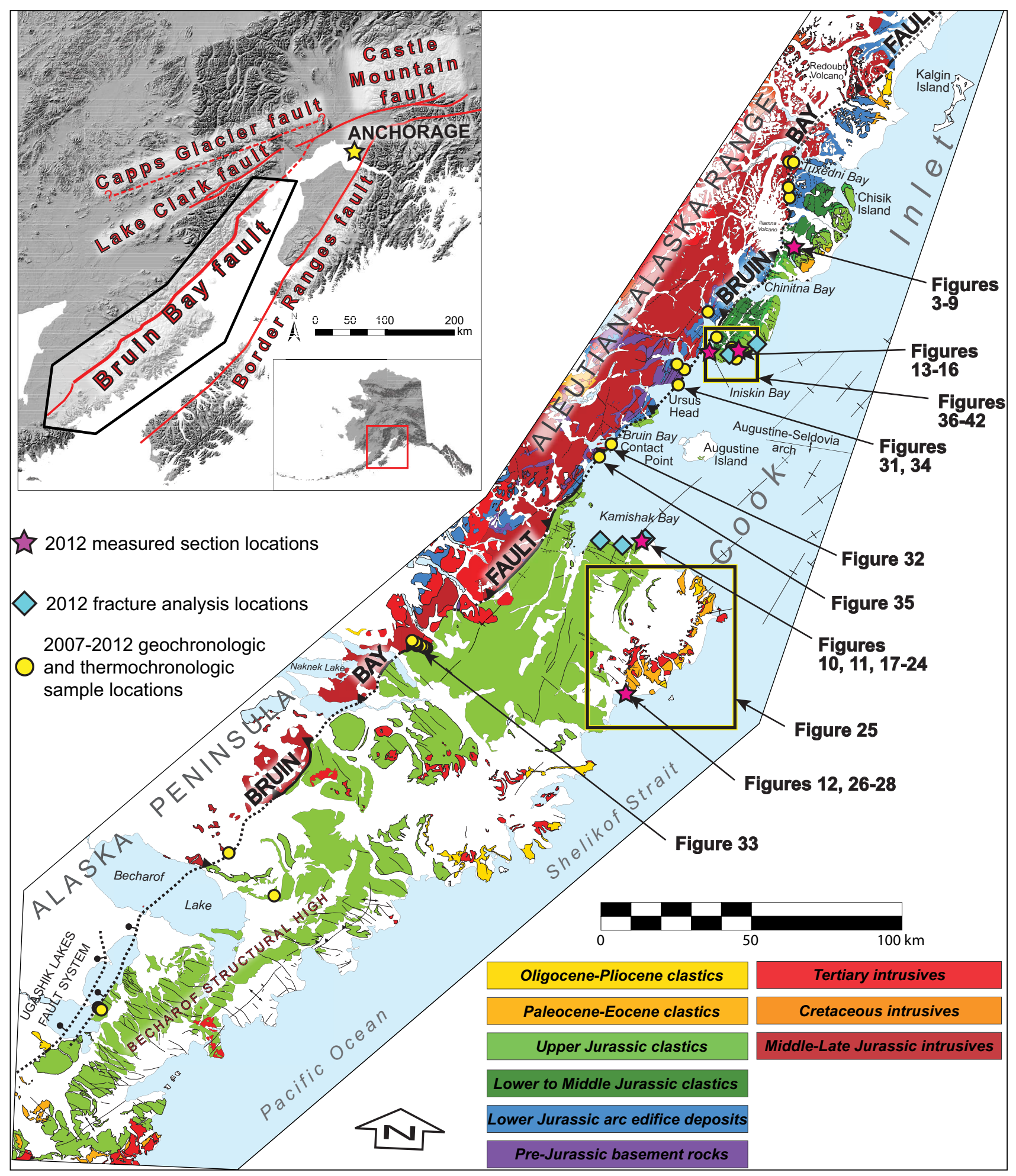

Figure 1. Simplified geologic map of the magmatic arc/forearc margin along the upper Alaska Peninsula and western margin of lower Cook Inlet (adapted from Wilson and others, 1999 and 2009) showing selected field locations discussed in the text that were visited by DGGS from 2007 to 2012. 


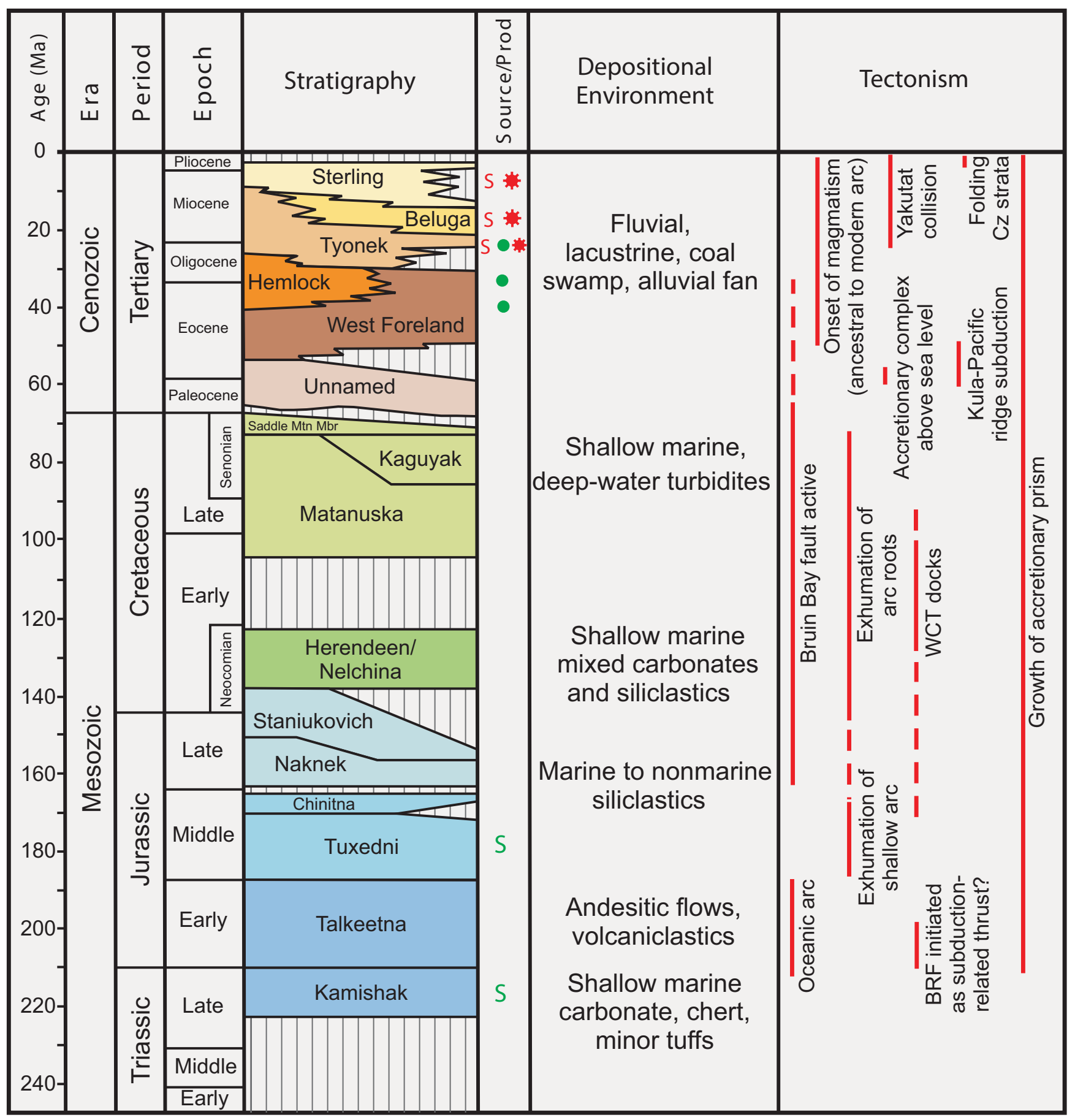

Figure 2. Generalized stratigraphic column of the Cook Inlet region. Redrawn from Swenson (2003); additional information added from Little and Naeser (1989), Nokleberg and others (1994), and Plafker and others (1994). 


\section{SIGNIFICANT FINDINGS}

- Organic geochemistry results from 19 samples collected from petroleum source rocks to Cook Inlet basin, the Red Glacier Formation of the Tuxedni Group, are overmature near their type locality on the flank of Iliamna Volcano. The high thermal maturity of the rock samples is possibly due to igneous heating related to the ancient or modern volcanic arc, deep burial beneath a thick interval of Mesozoic and Cenozoic strata prior to subsequent exhumation to the surface, or both.

- Naknek Formation samples from the Iniskin Peninsula-Tuxedni Bay region have highly feldspathic compositions and generally poor reservoir quality. However, in at least one location on the south shore of Kamishak Bay on the Upper Alaska Peninsula, hand lens observation of an oil-stained sandstone interval indicates that it has a substantially more quartzose composition. These observations suggest that sandstone composition can vary significantly in the Naknek Formation, and intervals that are more quartzose have the potential to serve as conventional petroleum reservoirs.

- Kilometer- to centimeter-scale systematic fractures found throughout the Mesozoic stratigraphy may represent significant fracture porosity and serve as migration pathways for liquid hydrocarbons into more porous Mesozoic and Cenozoic stratigraphic intervals.

- Two widely separated sandstone intervals in the Naknek and Kaguyak Formations on the upper Alaska Peninsula host oil-bearing strata that indicate past maturation and migration of liquid hydrocarbons in the region. The presence of several other locations in lower Cook Inlet where Upper Cretaceous strata are reported to be oil-bearing suggest that they overlie regionally extensive, thermally mature source rocks and might have potential as conventional reservoirs.

- The leading strand of the Bruin Bay fault is well exposed in coastal bluffs at Ursus Head and near Contact Point on the west side of lower Cook Inlet. Geometries associated with the moderately southwest-dipping fault plane are mostly contractile. However, steeply-dipping structures in the hanging wall arc-ward from the leading strand at these and several other locations exhibit mostly oblique-slip kinematics with mixed senses of motion and may cut lower angle contractile structures, suggesting that the fault system might record a more complicated slip history than previously understood.

- Detailed stratigraphic studies of the Naknek Formation in the Iniskin Peninsula area indicate rapid sedimentary facies changes in its oldest (Chisik Member) and youngest (Pomeroy Member) units that transition from boulder to pebble conglomerates proximal to the Bruin Bay fault to fine-grained sandstone and siltstones within a few kilometers distal to fault. This relationship suggests that the Bruin Bay fault was actively influencing sediment supply and accommodation proximal to the basin margin until latest Jurassic time. Sedimentary facies associations indicate an abrupt deepening of the basin prior to deposition of the Pomeroy Member, marking a major transgressive phase during Late Jurassic time. 